\title{
腎被膜涂離術ニヨッテ治瘾センメ得タル 慢性繊維性腎周圍炎, 1例
}

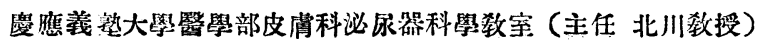

$$
\text { 金子榮壽 }
$$

Aus der Dermato. Urologischen Flinik der Medizinischen Fakultät der Keio

Gijuku Universität zu Tokyo. (Vorstand: Prof. Ir. M. Kitagawa)

\section{Über einen durch Dekapsulation geheilten Fall von Perinephritis fibrosa chronica.}

\author{
von \\ Dr. E. Kaneko.
}

Der Patient, ein 34jähriger Kontorist, litt seit etwa 14 Tagen vor seinem Besuch unserer Klinik an andauernden, zuweilen heftig auftretenden und manchmal aussetzenden, von Fieber bis $z u \quad 40^{\circ} \mathrm{C}$ begleiteten Schmerzen in der rechten Nierengegend. Vor dieser Zeit hatte er einen Furunkel am Oberschenkel gehabt, welcher mehrmals rezidivierte.

Der objektive Befund ergab aus verschiedenen internistischen und urologischen Untersuchungen keinen Aufschluss über die Genese des Leidens. Bei der Probeblosslegung der Niere an der erkrankten Seite zeigte das Organ selbst keine nennenswerten Veränderungen, jedoch war ihre Kapsel an ihrem oberen Pole verdickt und mit dem umgebenden Gewebe verwachsen. Nach der Ablösung dieser Verwachsung wurde die Decapsulation vorgenommen.

Nach der Operation blieb der Patient über 9 Monate hindurch völlig besch. werdefrei.

\section{Erklärung der Abbildungen.}

Abb. 1. Retrogrades Pyelogramm. Der Pfeil weist auf ein am Oberpol befindliches Kelchende mit unregelmässigem Schatten. Von abgelaufener Pyelonephritis zurückgelassene Narbe?

Abb. 2. Mikroskopisches Präparat aus einem Teile der exstirpierten Kapsel. Weist Blutung und Infiltration mit Rundzellen in der Umgebung der Gefässe auf.

目次

\begin{tabular}{|c|c|c|}
\hline 緒 & 言 & 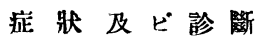 \\
\hline 經驗 & 例 & 治 \\
\hline 憕生原因 & 实理 & 結 \\
\hline
\end{tabular}




\section{緒}

\section{言}

腎, 周圍二於ヶル炎症八單二留周圍炎)名ヨ以テ總稱サレテハキルガ，之八詳シクハ次ノ如 クニ分類スベキデアル。郎チ

1. 粲繊維膜，炎症 ：Perinephritis

2. 脂肪䨟 $/$ 炎症 : Epinephritis

3. 留娞部脂肪組織,炎症：Paranephritis

之八Israel 二低ツテ初メテ記載セラレ, Pleschner モ Handbuch der Urologie =引用 シ，叉 Puscher モ Handbuch der Pathologie デ賛成シ，現今デハ一般カラ認メラレテ居ル 分類法デアル。

本邦デハ本间氏ガ Perinephritis 7 督周圍炎, Epinephritis 7 腎脂肪品炎, Paranephritis

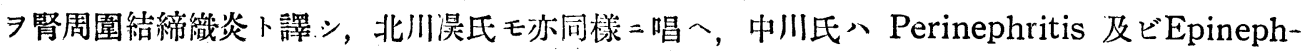

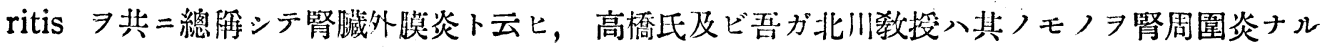

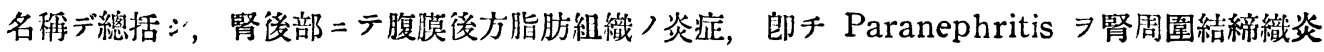
ト呼ンデキル。後省ニ就テハ中川氏モ亦同㥞ニ云ツテキル。

而シテ是等腎ノ周圍二於ヶル炎症ノ中デモ Epinephritis 乃至 Paranephritis＝屬スルモ，

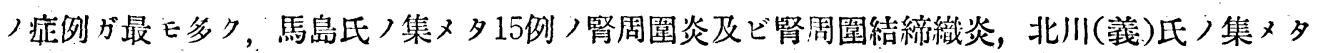
22例，其ノ他店例報告デ腎周圍炎トシテ記载サレテルモノ八總テ八所謂 Epinephritis 若ク八

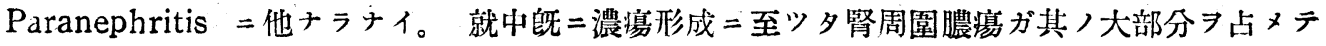
キル。

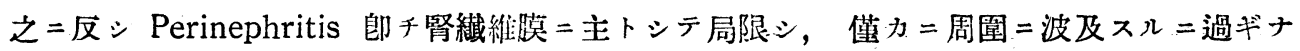

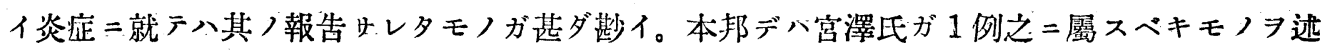
ペタガ，廣川氏ハ此ノ者八甚ダ稀ブ未ダ遭遇ンタコト八無イト特ニ云ツテ年ル。

Perinephritis モ更二之 7 分類シテ，繊維性(fibrose)，化膿性(eitrige)，肉芽性(granulierende) 及ビ漿液性(seröse) トナシ，此ノ中漿液性ノモノ八周圍性腎水腫ナル名稱デ角田氏

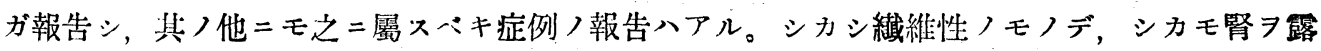

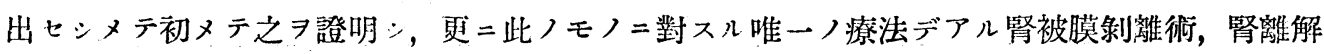

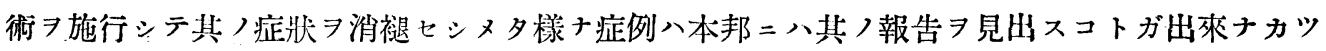
夕。只馬島氏，第13例が稍タ之二類スルカヨ惟ハシメルガ記載ガ不充分デアル。

外國，報告二八Perinephritis fibrosa =屬スルモ，八比較的多ク， Lichtenstern 八24例 ヨ集ヘテ報告シ，其)後 Gorasch /6例，Barcaroli，8例及ビVasiljev ノ同ジク8例ガア リ，Schwarz 八綜說的二詳シク本疾患二就テ記シテキル。

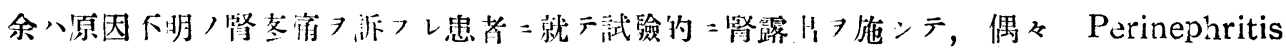




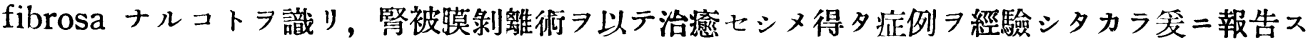
ル次第デアル。

\section{經驗例}

患 者 福土某。34歳男子, 會社員。 (入院 炤和10年11月 7 日)

主 訴 右側腎部疼痛及ビ惡寒 7 件フ發熱。

既往歷 約17年前蟲樣哭起炎 7 䍜患シ姑息療法 デ全治，其ノ後自覺症無シ。其ノ他二八何等著患 ヨ知ラナイ。

家族歴特別ナモノ無シ。

現症歴 7 月末左侧上退届側部二「フルンケル」 ヨ生ジ, 其レハ漸次腫大シテ膿痬トナリ, 8月5日 切開排膿 ガ數日ノ中二解熱シ, 切開創モ亦治癒シ夕。9月 25日即チ約50日 後二至ッテ, 上訅手術創ノ近ク ニ再ビ「フルンケル」ヨ生ジ, 前回ト同ジク腫大 シタタメ切開习受ヶ漸次快方二向ツタ。然ル $=10$ 月 2 日「ゴルフ」ニ行ッテ,「クラブ」ヨ10回程空振 シタ後デ急二右侧側腹部二疼痛 7 覺へ, 氣分モ亦 惡クナツタノデ,「ゴルフ」ハ止メタガ其/儘會社 二行キ, 份夜、慧橋迄苦痛 7 押シテ旅行シタ。車 中デモ疼痛ハ繼績シ且ツ發熱感 7 學エ, 柆 3 日八 該部二疼痛アリ们發熱ノタメ終日旅馆デ卧床シ， 4 日急遽歸京, 上某外科醫, 診 7 乞ツテ筋炎卜診

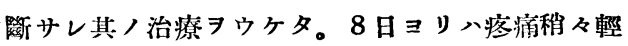
快シ, 該右側腎部 7 厴追スルカ, 步行スルカ, 若 クハ深呼吸 7 行フ時ニノミ强ク感ジル位トナツタ ガ, 發热八何 $39^{\circ} \mathrm{C}$ 域 7 保ツタ。

9 日先ヅ當大學外科 7 訪ヒ, 次デ內科二轉科セ ラレテ入院シ, 何 11 月 7 日二至ツテ吾科二轉科入 院シタノデアル。

內科入院後 5 日間入最高 $40.1^{\circ} \mathrm{C}$ 迄ノ不正型ノ發 熱ガアリ，腎部疼痛モ存續シ，該疼痛八患側部 7 下位二置キテ橫卧スル時稍々輕快シ氣持ヨイト云 ᄀ。

現 症 體格中等榮養稍々不良ナルモ內科的檢 索デ特別ナ病的所見八無イ。特二咽喉扁桃腺ニハ

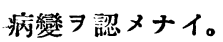

左側大腿內率部二於ヶル「フルンケル」手術創入
份潰瘍性トナツテ末ダ二全治二至ツテキナイ。 泌尿科的檢查二據儿モ，右側腎部二医痛アル以 外, 腎八兩側卜モ觸レズ, 膀睄部, 前位腺, 精囊 及ビ其レ等ノ啉图二病變ノ存在 7 認メズ。前位腺 部八尿道內二金屬「カテーテル」ヨ插入ノ上肚門內 ヨリ觸診シタガ病的所見习認メ得ナカツタ。除莊,

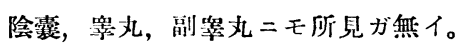

尿所見：排尿回數正常。尿八入院中數回二涉ッ テ檢查シ，時二「アルカリ」性デ炭酸石灰ノ結晶 7 含ンデ润濁スル車モアルガ, 多クノ場合八透明デ 酸性, 比重、1010-1026, 蛋白八稀二痕跡陽性ナル コトモアルガ多クハ㓌性, 糖モ亦陰性, 檢鏡シテ 赤血球ハ「ーサチラミン」注射ノ後 2 [回二於テ肉眼 的血尿ノ出现 7 來シタコトノアル以外二八常 $=$ 除 性, 保杜㓌性, 随球八時二数視野 $ᄏ$ 檢シテ數個認メ ルコトモアルガ除性ノコトガ多ク，其ノ他細菌若 クハ尿砂ヨ證明シタコトハー度モ無イ。

血液所見：血色素量 75\%「ザーリー」;

赤血球數 5280,000 ; 白血球數 9,500 ; 白血球， 種類…中性多核白血球 $€ 8.5 \%$, 淋巴球 $24.5 \%$, 單 核細胞 $6.5 \%$ ，「エオヂン」嗜好性多核白血球 0.5

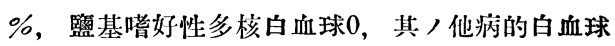
若クハ赤血球 $习$ 認メナイ; 赤血球沈降速度(「ウエ スターグレーン」) $30^{\prime} \cdots 50 \mathrm{~mm}, 60^{\prime} \cdots 62 \mathrm{~mm}, 120^{\prime}$ $\cdots 100 \mathrm{~mm}, 24$ 時間 $\cdots 125 \mathrm{~mm}:$ S. M. W $=40.5$.

血液「口」氏反應陰性。

「マントー」氏反應及ビ「ピルケ」氏反應共二險 性。

「ピエログラフイー」

1. 經靜脈性「ピエログラフイー」

「スギウロン」20.cc靜脈內注射, 厭迫帶 ズ, 注射後 5 分二於テ兩側卜モ腎觢, 腎孟像描出 シ，其ノ像二何等特別ナルコト無ク，30分二於テ 八雨侧卜モ其ノ像八消褪二傾ク。

2. 經輸尿管性「ピエログラフイー」

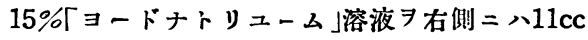


左側ニ 6.5cc注入シ，患者ガ激痛习訴へタル時 撮影入。

Abb. 1.

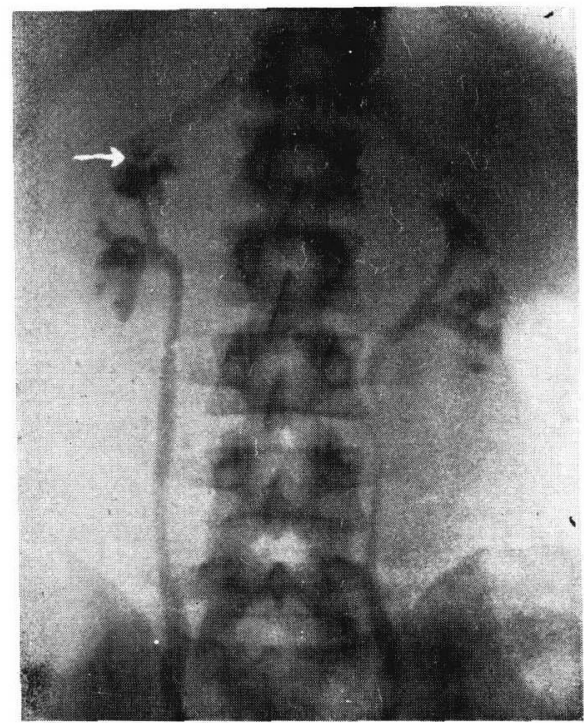

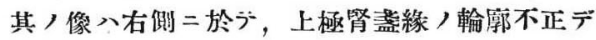
秘々實質內二山出スル像ヨ示シテキルガ, 腎孟, 其ノ他ノ腎盎及ビ輸尿管像ハ正常デアル。兩側卜 モ腎盂外造影劑溢流，像八描出シテキルカ，結石， 若ク八腫瘍等, 存在ヨ示ス所見八觀ラレナイ。輸 尿管/病的排張モ亦登セラレナイ。(附圆 $\mathrm{Abb}$. 1 . 參照)

膀胱镜檢查及ビ輸尿管「カテテリスムス」

膀胱容量正常，粘膜及ビ兩側輸尿窝口二病的所 見ヨ認メナイ。輸尿管「カテーテル」一兩侧卜モ容 易二挿入シ得テ分離尿 7 探取ス。

其, 尿/右侧 $\Xi$ リ $モ$ 二極メテ僅カ二膿球 7 認メル以外二八何等特別ナモノガナイ。

腎機能檢查

1.「インデゴカルミン」排泄試驗( $1 \% 5 \mathrm{cc}$ 靜脈 内)。初發右…4 $4^{\prime} 15^{\prime \prime}$, 左…4 $4^{\prime} 45^{\prime \prime}$, 濃素右‥5 $5^{\prime} 20^{\prime \prime}$, 左. $\cdots 5^{\prime} 05^{\prime \prime}$

2.「フェノールズルフオフタライン」排泄試 驗。30分間‥51\%，1时間‥14\%，2時間13\%

3. 水試羷( $1200 \mathrm{cc}$ 攝取)。4时间排浽量 $1153 \mathrm{cc}$. 比重差 $0 \sim 24$
師チ之ヨ要スルニ右側腎部ノ激シキ自覺痛及ピ 不定且ツ不規則ナ發熱 7 以主派卜スルガ, 他覺

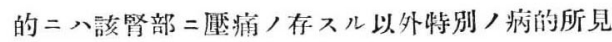

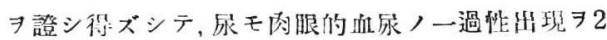
回認メタコトアル以外ニハ始ンド全ク正常デ，腎

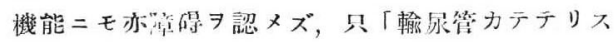

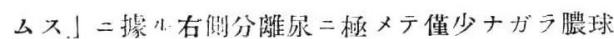

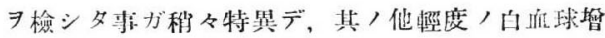
多及ビ赤血球濯降速度ノ明カナ光淮,ミガ最モ著 明ナ他毿的病的所見二過ギナイ症侧デアル。

而シテ經輸尿管性「ピエログラム」ニ於テ, 右側

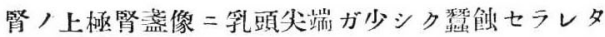
カヨ惟ハ七ル樣ナ所昌 核ノ初期症デメナイカ 膜二炎症ガアルノデ、焎イカ $7 モ$ 想像シタ。爱二 於テ11月16日武驗的珡露出シ敢行スル二至ツタ。

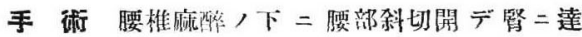

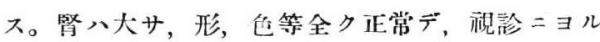

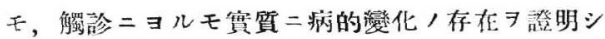
得ナイ。只之 7 創外二脫出セシムルタメ居圍脂肪 組織 $コ$ 剝離セントスル时, 上端部特二其, 前面二 於テ脂肪組織及ビ其ノ周圍卜互二强ク虑普シテ分 蜼二困難

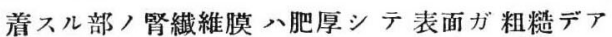
几。

Abb. 2 .

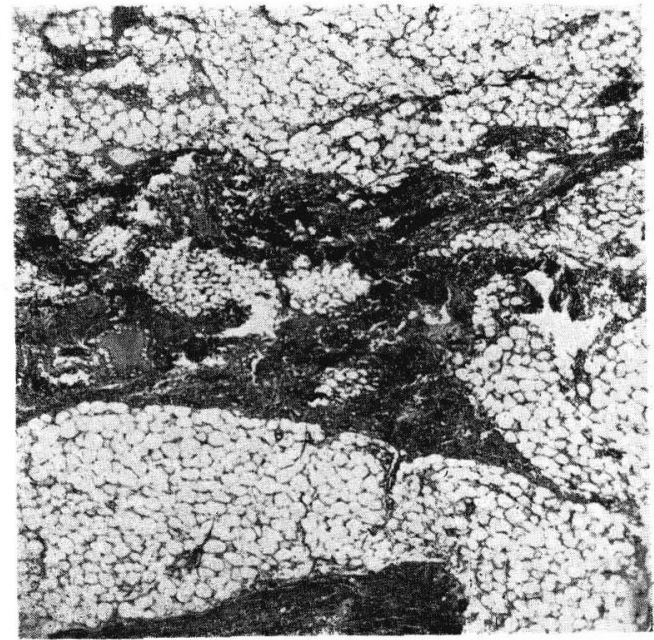


腎被膜剥離術ヨ施サント其ノ部ノ纎維膜二達ス ルニ，其レ八腎賽質ト密二瘾合シテ無理二剝ガサ ントシテ珡實質ノ一部习約拇指頭大二缺損セシメ テ出血シタ。故ニ「パクレン燒灼器デ燒灼シテ止 血 $\exists$ 施ス。督八更二克分遊離ノ狀態トナシ，剩離 シタ全面/被膜 $习$ 切除ノ上㓣队二放置シテ術 7 終 ッタ。

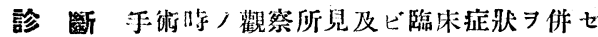

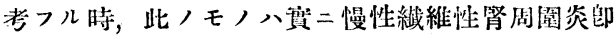
チ慢性瀻維性腎繊維膜炎ニ他ナラナイコトハ明カ デアル。

手術後/經過 手術創八一時化譨シテ發熱

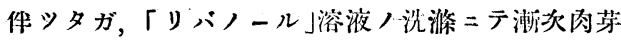
織，设有良好ト+リ，手術後34日.目二全治退院シ
夕。手術前ノ腎部疼痛八手術卜共二拭フガ如ク二 消失シタノデアル。其ノ後今日范 9 ケ月二至ルガ 患者八全ク健康デ其ノ職務ニ從事シテキル。

切除腎被膜/病理組織舁的所見 本標本八癒着 部位ヨリ少シク離レタ部ノモノデアル。纎維性組 織卜脂肪組緎ヨり成ツテ，前者 7 檢スル二結締織

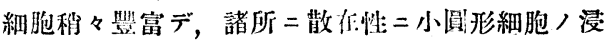
潤 觀儿。址管八援張光盈シ，動脈壁八肥厚シ，

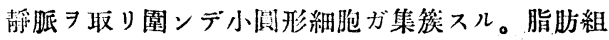
織 カ浸潤シテ牛ル。(附圖Abb. 2. 參照)

即于瘾着局部二近接スル被膜二於テモ明カ二炎 痁症状，存スルコトガ理解出爽儿。

\section{墢生原因姂ビ病理}

本疾思，原因八Illyés ノ症例ノ如ク二尿酸結晶ガ腎表=渗出シテ起ツタモノハ例外トシテ， 其ノ他ノ腎被膜乃至其ノ周圍ニ於ヶル總テノ炎症二於ヶルト同ジク細菌＝因ルモノガ多イ。北 川(義)氏八腎周圍＝於ヶル炎症症例＝就デ病原菌习哳究シ，22例ノ中19例ガ單一ノ菌二因ツテ

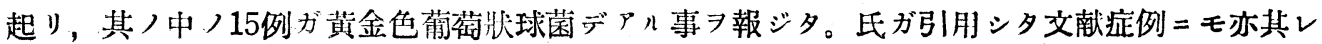
ニ一致シテ葡萄狀球菌＝因ルモノガ多イ。

氏等ノ檢シタ症例ハ多ク既二䁸癔二至ツタ症例デアルガ，本疾患ノ如ク二慢性二經過シテ化 膿スル傾向ノ尠イモノニ於テハ，其ノ原因菌ハ病原性ノ弱イモノ=因レルコトハ想像ニ難クナ 1。

本疾患ノ發生經路八腎被膜乃至其ノ周園ノ炎症ノ總テノ場合卜同㮏二，腎臓部ノ外傷二原 因シ，若ク八腎內八諸種疾患，腎二近接スル贜器，及ビ腎卜淋巴管习以テ連絡スル臟器カラ波 及蔓延スルコト =因ルノデ, 蟲栐突起炎, 生殖器周圍炎等モ此ノ原因トシテ舉ら゙ラレテ居ル。

其ノ他重要ナノ八遠隔部ノ局在性化膿性疾患，例へバ「フルンケル」，「カルブンケル」等カラ 血流性二傳播サレテ起ルコトデ， Lichtenstern，咽喉炎特=扁桃腺炎力原因トナル場合ノ继 シク多イコトヨ示シテキル。

余ノ本症例デハ上螁部二荏英治ラナイ「フルンケル」カ゚アツデ 2 度モ切開手術ヨウケ，本疾患

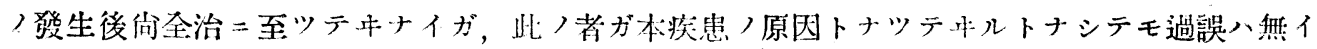
ト信ジル。

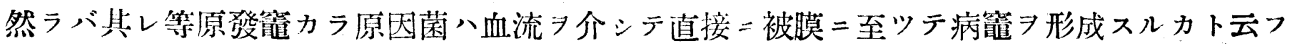

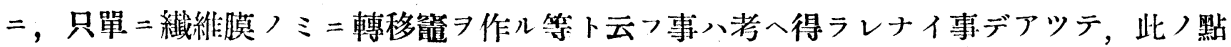




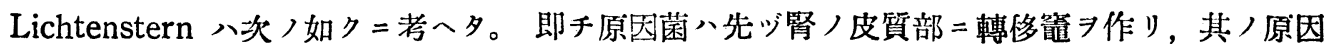
菌八病原性ガ弱イタメカ若ク八腎ノ抵抗ガ强イタメ二䁸廈形成二八至ラズシテ治癒二向七，只 纎維膜=迄波及シタモノガ其ノ部二炎症症狀 ノ自己症例ノ中 7 例 $=$ 於テ皮質部 =病變ノアッタコトヨ組織學的二確メテンル。Schwarzモ亦

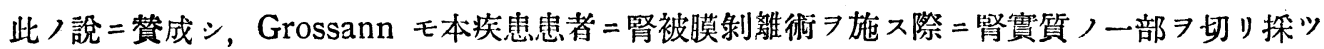

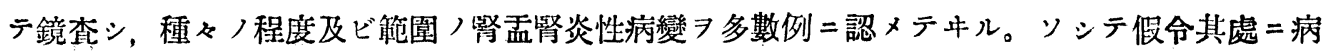

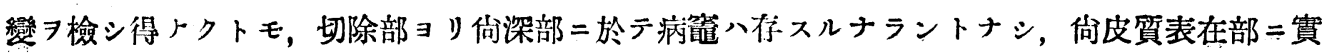

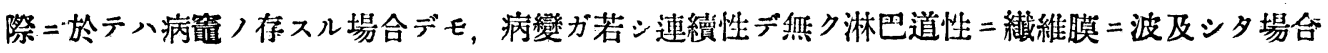

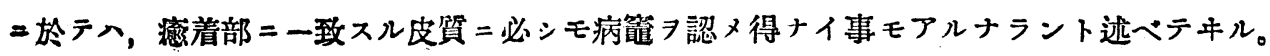

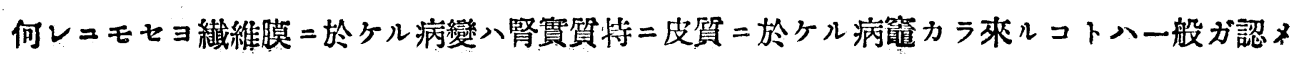
テキル事筫デ，余ノ本症例デモ「ピェログラム」於テ上極腎盖像二不正形ヨ示シテキル事へ， 其ノ腎盛二屬スル貫質=何等カノ變化アルラ思惟セシメルモノデアルシ，其ノ部が刃手術ノ際 二觀タ上端部ノ病變部 $=$ 一致シテル事モ, 本例ノ此ノ纎維膜病變力腎實質 $=$ 存在スルカ若クー 敀テ存在シタ病變二因由シテルコトヨ肯定セシメル。

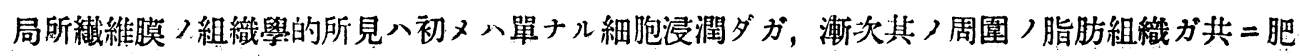
厚:, 又結締織八增殖シテ肥厚シタ間壁八脂肪組織ノ中 $=$ 梁狀 $=$ 浸入スル。余ノ本例モ亦斯力

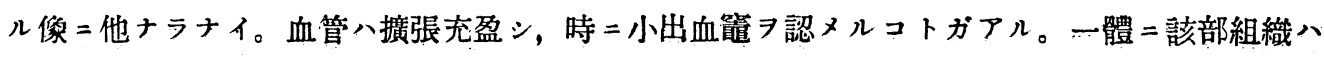
浮腫狀デ其ノ中 = 種々ノ量及ビ形デ炎症性細胞浸潤がアリ, 其ノ多ク八淋巴球樣細胞及ビ「ワ゚.ラ スマ」細胞デ，一部八血管 7 包圍シ，一部八洧蔓性 =散在 スル, 其ノ他中性多核性白血球 7 混 ジル事ガアル。又非常二多數ノ「エヂン嗜好性白血球 症症狀八又脂肪組織 $ᄏ$ 刺皒シテ其ノ增殖 $ᄏ$ 促シ, カノ纎維脂肪型(fibrolipomatöse Form) 卜 稱七ラレルモノ八結締織卜脂肪組織トカ密二編ミ合ツテ肉眼的 $=$ 八非常 $=$ 厚クテ鎧板ノ如ク =

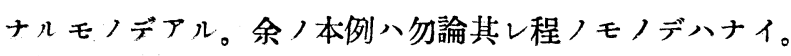

\section{症 狀 及 ビ 診 斷}

最モ主要ナ症狀八腎部ノ疼痛ニ他ナラナイ。Lichtensternハ本疾患が有痛性筒炎(Nephritis dolorosa) 若タ八疝痛性腎炎(Nephritis colica, Koliknephritis) ノ名ノ下=呼バレテキル事 尹述へ, Gorasch 八有痛性腎周圍炎(Perinephritis dolorosa) ナル橴題ノ下 デル。余ノ本例モ亦腎部疼痛习主訴トスルノデブル゙, 此, 疼痛八成書 $=モ$ 示サレテ居ルガ 如ク多栐デ, 單二腎部ョリ腰部二亘儿不快感若ク八重盅感トシテ認メラレ,タメ二腹部臟器,

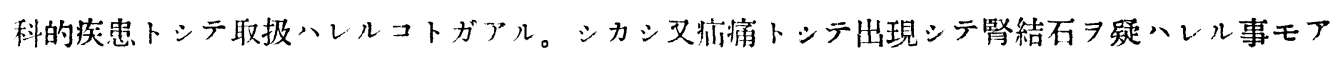
ルガ之八稀デアル。斯カル疼痛八普通運動若ク八安靜二八關係シナイガ, 時二八體動, 特=腰

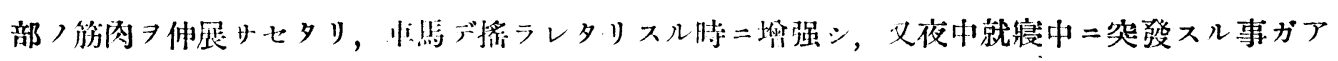


ルト云フ。Gorasch, 疼痛ノタメ二身體シ動カシ得ナイカ若ク八動カス事ヨ忌ム症例卜, 其 ノ反對 $=$ 七轉八倒シテ安靜ヨ致セナイ症例ノアルコトヨ述ベテキル。

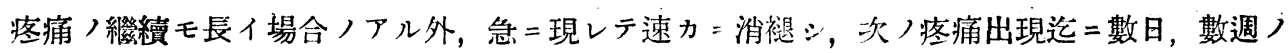
間隔ノアル場合ガアル。

其ノ他疼痛八反射性二他側, 腎部ニモ現ハレ, 叉背部, 肩部=傳ハル事ガアル。然シ結石; 場合ノ如クニ瓜路ニ沿ツテ下方=傳儿モノ八無イト云フ。

余ノ本症例ノ疼痛八時二八激シク持續シ，其レハ歇ンデ數日間自發痛無ク，又身體ヨ動カス コトニ由ツテ出現スルガ, 斯カル疼痛八患側 テ卡方二傅ハルコトハ之ヨ否定シタガ, 他側腎部シ八輕度ノ疼痛习訴ヘル事ガアツタノデア ル。

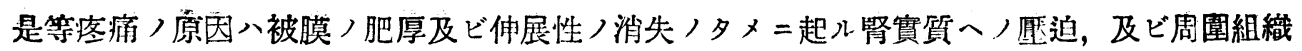
卜ノ痹着=因儿腎, 可動性)障碍 膜 /炎症及ビ肥厚

以上腎部疼痛ノ外二八泌尿器系疾患ナルコトヨ惟ハシメル樣ナ症狀ハ明カデ無ク, 此ノ事ガ 實二本疾患ノ特徵トモナルノデアル。尿二蛋白, 圓柱等病的所見 モ寧口例外デアル。只血尿二就テハ腎疼痛發作ノ後 =於テ輕度二出現シタモノノアルコトラ Gorasch 八述へ，又 Alberti ノ報ジタ症例二於テモ血尿 $\Rightarrow$ 件フ腎部疼痛ガ局在性出血性腎炎 及ビ腎被膜, 肥厚二由來シ, 腎被膜刎離獄デ洽癒シデル。

余ノ本症例モ一過性血尿 72 回觀夕ガ，腎疼痛，發作卜ノ間ニハ特別ナ關係引認メ得ズシテ 寧口「ウトロピン濟制/静脈內注射卜ノ間二關係アルモノノ如クデアル。而シテ藥劑ノ剌㦸デ血 尿ノ出現スルコト八腎二病變ノ存在ヨ示ス證佐デハアルガ, 血瓜時二詳細ナ檢索 ツタノデ傕カナ關係ハ之ヨ知ルコトヨ得ナイ。

上述ノ如クニ本疾患八單＝腎部疼痛习主訴トナシテ，其／他二診斷ノ指針トナル症狀ガ無イ タメ二臨床上倠定的診斷 ヨ與ヘルコトハ困難デアル。

腎部疼痛八外科的腎疾患つ種々ナル場合＝認メラレ，就中腎結石症八其，第 1 =數フベキモ ノデアル。余ノ本症例モ內科二入院當初ョリ腎結不ノ疑七ヨノ、持タレテ經過シタモノデア ル。而シテ腎結石ノ場合,「レントゲン像一結石ノ影像尹求メ得ズトモ結石ヨ否定シ能ハザル コトノアルコトハ, 本疾患ヨシテ益々結石症ヨ疑ハシメルノデアル。余ノ本症例八其ノ他ノ症 狀及ビ檢查デ結石症，否定セラレルコトハ勿論デ，特二腎露出ガ此ノ事ヨ充分ニ示シテキル。

同ジク腎部庝痛ヨ訴フル疾患デモ腎孟炎, 緊絬核, 腎水腫及ビ腎腫瘍入其レ等ノ有ス几獨特ノ 症狀及ビ「ピェログラム」像デ容易＝鑑別出來ルガ，腎結核デ原因菌，證明不能，時，瓜所見； 輕微ナル時等ニハ注意 7 要シ, 余モ亦一時本症例 7 腎結核ニ非ルカヨ疑ツタノデアル。杉村氏 
モ同樣ナ經驗例 7 脂肪聚炎二就テ有スト述べテキル。

「レントゲン」診斷二就テハ, 先ヅ宫澤氏ハ氏ノ第 1 例ガ，其ノ像＝腎周圍組織ノ肥厚 シ現ス コト ヨ根據＝腎周圍炎卜診斷シ，Laurell 八腎周圍ノ高度ノ病變殊二䁸瘍形成二至ツタモノ八 診斷シ得ルコトアルト報告シテキル。然シ本疾患ノ如ク二疬變ハ殆ンド瀻維膜二局在シテ,腎 露出シデ一見其ノ形二變化，無イモノ八到底「レントゲン」像二其ノ病變ハ描出セラレナイ。 「ピェログラム」デ腎實質＝病變习認メルコトハ, 其レガ假令尿 =病變所見习現ス程活動性=非

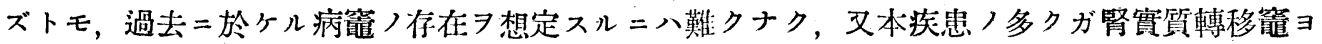
リ續發スト思惟サレルコトハ,此ノ想定二一致スルモノト云へル。

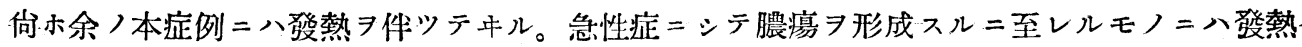
ハ必發つコトデアルガ, 慢性症デ其ノ組織學的所見ニモ炎症症狀ノ强ク無イ時:之ヨ觀ルコト 八一見矛盾スルガ如クデハアルガ，本症例 =於テ發熱八必ズ疼痛二一致シテ出現スルコト，諸

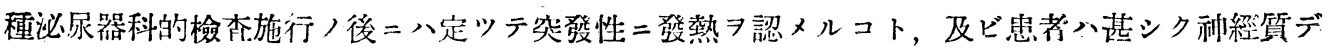
アルコト等ヨリ推シデ, 之ハ必シモ炎症性病簡二明ツテ起レルモノニ非ルコトラ推测シ得ラレ 几。又輕度ノ白血球增多及ビ比較的著明, 赤血球沈降速度ノ尣進八大腿部ニ於ヶル「フルンケ ル」二支配七ラレテキルトモ思惟シ得ベクシテ, 特二重要ナル意事习之ノミニ附スベキデハナ i。

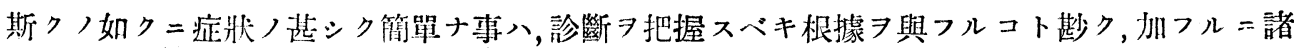

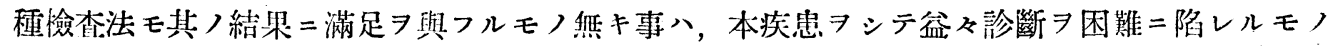
デ, 最後つ診斷八實二試驗的腎露出二俟夕ネバナラナイト云ハネバナ゙ラ 。

治

療

本疾患八病理學的二其ノ病變比較的弱ク, 且ツ進行性ノ態度 ヨ示スコトモ尠イタメ, 姑息的療 法ガ充分目的 達シ得ルガ如クデハアルガ, Lichtenstern ヨ初メ Gorasch, Schwarz 等八 其ノ効果赻トコトヨ述ヘテ, 專う腎被膜剩離術, 腎被膜部分仢切除術, 若クハ腎離解術ヨ施シ テ初メテ治癒スルコトヨ述ベテキル。

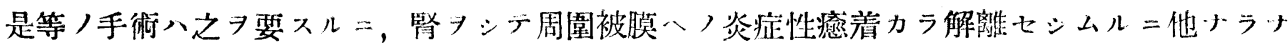

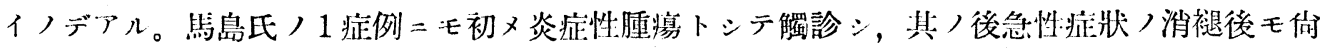

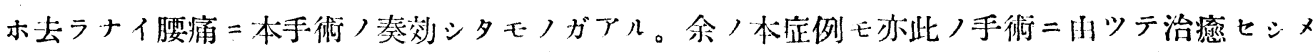
得夕モノデ, 余八手術的操作, 簡單デ, シカモ危險 デアル。

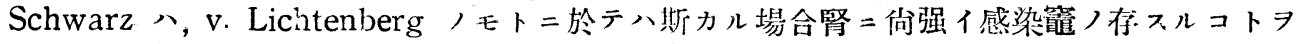

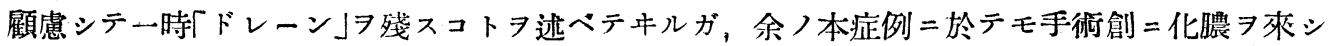
タコトハ, 或ハ此ノ要アリシカヨ惟フノデアル。 


\section{結 論}

34歲會社員, 右側腎部=强度ノ持續性疼痛习訴人, 其レハ時=消長ガアリ，且ツ不正型，發 熱 件フ。

內科的及ビ泌尿科的諸種檢索デ其ノ病的原因ヨ確定サセルコトヨ得ナカツタタメ，試驗的腎

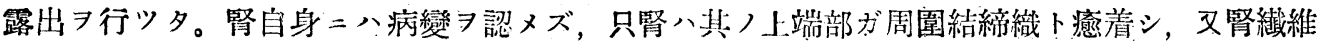

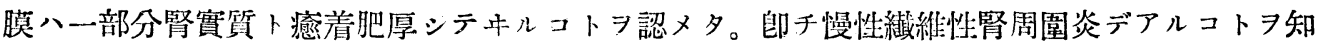

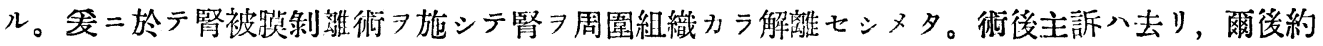
9 ケ月ヨ經過スルガ㭧者八全ク健康デアル。

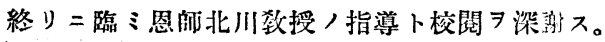

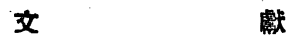

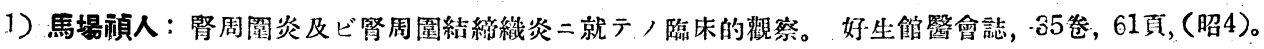

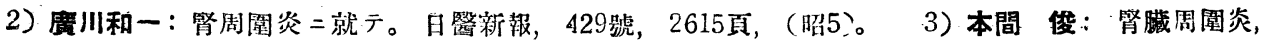

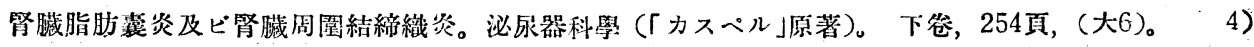

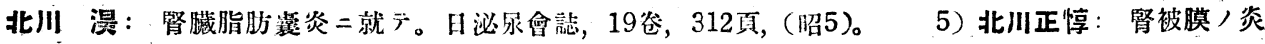
淀。最近泌尿器科學, 205頁, (炤10)。北川義夫 : Zur Statistik der paranephritis, mit besonder Berücksichtigung ihres Erregers. Mitteilung über allg. Pathologie u. path. Anatomie. Bd. S, S.

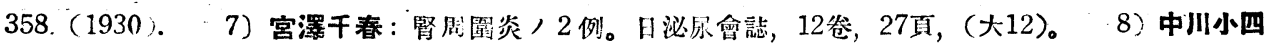

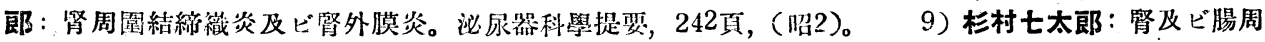

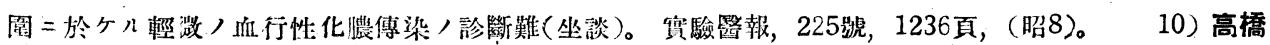
明：腎周圍結締織炎（满義）。東西醫學，4谷，25淲，(炤4)。 bei nephralgischer Niere. Ref. Z. f. urol. Chir. Bd. 35, S. 272, 1932 12) Barcaroli, I.: Die chron. schmerzhaften primitiven Perinephritiden. Ref. Z. f. urol. Chir. Bd. 33, S. 155, 1931. 13) Gorasch: Perinephritis dolorosa und ihre Behandlung. Z. f. Urol. Bd. 20, S. 589, 1926. 14) G cssman , W.: Hi tologische Befunde bei den chronisch entzündlichen Erkrankunger der Nierenhüllen. Z. f. urol. Chir. Bd. 20, S. 79, 1930.115$)$ Il yés, G. v.: Fibröse Perinephritis bei harnsaurer Diathese. Fol. urol. Bd 6, S. 691, 1912. 16) Laurell, H.: Ein Beitrag zur Röntgendiagnostik der Peri- bzw. Paranephritis. Ref. Z. f. urol. Chir. Bd. 9, S. 180, 1922. 17) Lichtenste n, R, : Perinephritis. Ref. Z. f. urol Chir. Bd. 8, S. 140, 1922 . 18) Pleschner, H. G. : Die Entzündungen der Nierenhüllen. Wildbolz's Handbuch der Urologie. Bd. 3, S. 667. 19) Puschar, W : Entzündliche Erkrankungen der Nierenhüllen. Lubarsch u. Henke's Handbuch der spez. path. Anatomie u Histologie. Bd. 6, Teil. 2, S. 456, $1934 . \quad 20)$ Schwarz, A O.: Klinische Erfahrungen über die chronischen entzündlichen Erkrankungen der Nierenhüllen. Z. f. urol. Chir. Bd. 2 ; S. 38, 1929 21) Schwarz A. O.: Beitrage zur Röntgendiagnose der nicht eitrigen Perinephritis. Z. f. Urol. Bd, 23, S. 1007, 1929 . 22) Schwarz, A. O.: Beitrage zur Klinik der chron. entzündlichen Nierenhüllenerkrankungen. (Perinephritis) $Z$. f. urol. Chir. Bd. 35, S. 114, $1932 . \quad 23)$ Vasiljev, A.: Zur Frage derNephritis dolorosa. Ref. Z. f, urol. Chir. Bd. 33, S. 275, 1931 , 